\title{
The dynamics of farm milk price formation in Brazil
}

\author{
Kennya Beatriz Siqueira ${ }^{1}$ \\ Richard Lee Kilmer ${ }^{2}$ \\ Antônio Carvalho Campos ${ }^{3}$
}

\begin{abstract}
Dairy is a highly relevant segment of the Brazilian agribusiness economy. However, this segment has changed significantly after deregulation Thus, it is worthwhile to know what the changes are in the spatial integration of the market and in milk price formation at the farm level after deregulation. The methodology is a modification of Gonzalez-Rivera \& Helfand (2001), which is compounded in extension of the market, pattern of integration, and degree of integration. The extension of the market is determined through the measure of self-sufficiency index, unit root test, and Johansen test. The last one is focused on the searching for a common trend between the time series. The pattern of interdependence is studied using the Directed Acyclic Graph (DAG). Lastly, the degree of integration is measured by the impulse response functions derived from the Bernanke decomposition. As a result, we found that the milk market in Brazil is composed by Goiás, Mato Grosso, Mato Grosso do Sul, Minas Gerais, Paraná, Rio de Janeiro, Rio Grande do Sul, Santa Catarina, and São Paulo. We also discovered that these markets have small speed of adjustment to shocks and there is no leader in milk price formation.
\end{abstract}

Key-words: market integration, milk market, price formation

\footnotetext{
${ }^{1}$ Engenheira de alimentos, com mestrado e doutorado em Economia Aplicada pela Universidade Federal de Viçosa. Pesquisadora da Embrapa Gado de Leite. E-mail: kennya@cnpgl.embrapa.br

${ }^{2}$ Economista agrícola, com mestrado na mesma área pela Purdue University. Doutorado em Economia Agrícola pela Ohio State University. Professor do Food and Resource Economics Department da University of Florida.

${ }^{3}$ Engenheiro agrônomo e mestre em Economia Rural pela Universidade Federal de Viçosa. Doutorado em Economia Agrícola pela Oklahoma State University. Atualmente é professor titular no Departamento de Economia Rural da Universidade Federal de Viçosa.
} 
Resumo: O setor lácteo é um segmento de grande relevância no agronegócio brasileiro, mas vem passando por mudanças significativas desde a sua desregulamentação. Portanto, é interessante conhecer as mudanças na integração espacial do mercado e na formação do preço do leite ao produtor após essa desregulamentação. A metodologia utilizada é uma modificação de Gonzalez-Rivera \& Helfand (2001), que é composta de extensão do mercado, padrão de integração e grau de integração do mercado. A extensão do mercado é determinada por meio da medida do índice de autossuficiência, teste de raiz unitária e teste de Johansen. Este último é focado na procura por uma tendência comum entre as séries. $\mathrm{O}$ padrão de integração foi analisado usando o Directed Acyclic Graph (DAG). Por fim, o grau de integração de mercado é medido pela Função de Impulso-Resposta derivada da decomposição de Bernanke. Como resultado, foi encontrado que o mercado lácteo brasileiro é composto por Goiás, Mato Grosso, Mato Grosso do Sul, Minas Gerais, Paraná, Rio de Janeiro, Rio Grande do Sul, Santa Catarina e São Paulo. Foi verificado que o mercado lácteo tem uma baixa velocidade de ajustamento a choques e não há um líder na formação do preço do leite entre os estados brasileiros analisados neste estudo.

Palavras-chaves: integração de mercado, mercado lácteo, formação de preço.

Classificação JEL: C22, L11.

\section{Introduction}

Studies about market analysis have become very popular in the academic environment. The mainstream in economics defines market integration as the satisfaction of the Law of One Price (LOP) or as the existence of cointegration between price series. Fackler \& Goodwin (2000) adopted the idea that market integration is a measure of the degree to which demand and supply shocks in one region are transmitted to another. For Barrett (2001, p. 20), "market integration represents the Walrasian transfer of excess demand from one market to another as captured in actual or potential physical flows". However, Gonzalez-Rivera \& Helfand (2001) interpreted that the existence of market integration is related to two conditions. Firstly, the set of locations should be connected by a physical flow of goods. It is necessary to ensure that arbitrage occurs, but by itself, it does not guarantee market integration. Secondly, the prices between the regions should share the same long-run information. In a cointegration framework, it is equivalent to require the existence of one and only one integrating factor, which is common to all series of prices. The Gonzalez-Rivera \& Helfand's market integration definition seems like the most appropriate approach for this study. It is an interesting definition because it requires that both goods and information be correlated between the regions. Therefore, we are going to use the 
Gonzalez-Rivera \& Helfand's methodology in order to analyze the dynamics of farm milk price formation in Brazil.

Gonzalez-Rivera \& Helfand (2001) studied the Brazilian rice market. They divided the market integration analysis in three steps, which include measuring the extension of the market, the pattern of integration, and the degree of integration. As extension of the market, they understand the regions that present continuous flow of information and trade. It was identified by the long-run relationship on the cointegration model. The pattern of integration means interdependence on locations and was measured by the Vector Error Correction (VEC). The degree of integration captures the speed of price adjustment and was calculated with persistence profile.

The Gonzalez-Rivera and Helfand approach has also been used by Liu \& Wang (2003), Pereira (2005), Rashid (2004), and Moser et al. (2005). Liu \& Wang (2003) studied the egg market in six Pacific States. Pereira (2005) analyzed the cattle market in Brazil. However, she extended the Gonzalez-Rivera and Helfand approach by studying the determining factors for the market integration. As explicative variables, it was considered physical capital, production, consumption, etc. As a result, Pereira (2005) found that eleven states of Brazil are integrated and São Paulo is a leader of price in the short-run.

On the other hand, Rashid (2004) studied Uganda maize market after liberalization. He analyzed extension of integration, causality among spatial locations, and the relative importance of spatial regions in price formation. Therefore, he made use of Gonzalez-Rivera \& Helfand (2001), Gonzalo \& Granger (1995), Masconi \& Gianninni (1992), and Hall \& Milne (1994)'s approaches. The results suggested that a small number of market locations, mainly large consumption and production districts, dominate the long-run price transmission.

Finally, Moser et al. (2005) innovated by using a rich database. They had data on rice prices, transaction costs, and infrastructure availability for Madagascar. This data permitted them to measure market integration across space, time, and form. They examined the extension of the market in sub-regional, regional, and national scales. The results showed that markets were well integrated at a sub-regional level and that factors such as high crime, remoteness, and lack of information were among the factors limiting competition. A lack of competition persisted at a regional level and high transfer costs impeded spatial market integration at a national level.

In spite of using Gonzalez-Rivera \& Helfand's methodology, we took a different approach by incorporating the Direct Acyclic Graphs (DAG), Bernanke decomposition, and Impulse Response Functions. The DAG was preferred to VEC because it allows us to see the contemporaneous relationship among the variables. It also shows clearly the direction of causation and the leader in price formation. To analyze the degree of integration, we chose the impulse response functions because it measures the individual shocks in the variables, instead of wide-shocks (persistence profile). Lastly, to do the impulse response functions, it 
is necessary to treat the innovation accountings from the VAR. In order to do this, we opted for using the Bernanke decomposition in association with DAG, since the Choleski decomposition (the most common decomposition) presents the problem that a recursive ordering may be overly restrictive.

\subsection{The Brazilian Milk Market}

Dairy is a highly relevant segment of the Brazilian agribusiness economy. In 2006, the Brazilian milk production was roughly 25 billion liters, which insert Brazil in the sixth position in the world ranking (EMBRAPA, 2008).

However, there is a significant heterogeneity among dairy farms. Large dairy farms, with elevated productivity indexes, are located among small traditional dairy farms that work with rudimentary techniques of production. It results in great differences between the production systems used by small and large dairy farms. The small dairy farms represent $80 \%$ of the producers and are responsible for $20 \%$ of national production, while $20 \%$ of the dairy farms are classified as large and represent $80 \%$ of national production (GOMES, 2003).

Historically, domestic milk consumption has exceeded domestic production. Brazil is characterized as a net importer of dairy products with annual purchases in the order of one billion liters (MILKPOINT, 2005). More recently, Brazilian dairy exports, which have been traditionally sporadic and of little significance, have experienced growth.

Federal governmental intervention in the dairy sector is an important part of Brazilian milk history. In 1945, the government began the intervention at both the farm and retail level. The regulation of the milk price, in association with a closed economy, had a protectionist character, which delayed the modernization of the dairy industry (GOMES, 2003). It persisted with lower levels of productivity, elevated costs of production and lower quality products (MARTINS, 1999).

In 1991, the government decided for the liberalization of the milk segment. After deregulation, the dairy farm production sector showed relevant technological development, which is verified by increased rates of growth in productivity and milk production (GOMES, 2003). However, in the context of post liberalization, high levels of price instability started to be observed at the farm level, leading to repeated demands for government intervention in the transactions between farmers and processors.

Indeed, even after more than one decade of deregulation, significant advances have not yet been observed in the vertical coordination between farm milk production and the distribution chain (GOMES et al., 2002). Typically, there is no price, quantity or any other production or marketing commitment formalized in the supply chain relationships between farmers and processors, like contracts, options, or futures markets. By and large, these chain actors have to cope permanently with uncertainty regarding quantities, quality, prices and other related variables (GOMES et al., 2002). 
On the other hand, there was a change in milk production regions. In 2002, the largest growth in farm milk production occurred in Northern Brazil, with an increased of 325 million liters. With a yearly output of $29.16 \%$ of national production in 2001, Minas Gerais ranks 1st among the country's largest milk producers, followed by Goiás with $11.32 \%$, Rio Grande do Sul with $10.83 \%$, Paraná with $9.21 \%$ and São Paulo with $8.69 \%$. Therefore, São Paulo, the traditional milk producer, has decreased in rank (EMBRAPA, 2003).

The region Center-West has been notable in milk production. This region, mainly Goiás, has shown increasing rates of growth in milk production. In Minas Gerais (region Southeast), farm milk production has relocated from traditional dairy regions, like the South, Southeast, and Zona da Mata to the Triângulo Mineiro and Alto Parnaíba. This relocation was caused by a reduction in production costs, which made Brazilian dairy products more competitive with imports (TANNÚS, 2001). It represents a possibility of acquiring inputs at lower prices, because dairy farms are closer to the largest grain production regions (GOMES, 1997).

Another important part of the dairy sector is long-life milk, called Ultra High Temperature milk (UHT). UHT was introduced in Brazil in 1972, but it only began to be successful in the 1990s. Since then, sales have increased an average of $27 \%$ per year. The market share of UHT milk in the fluid milk market rose from $4.4 \%$ in 1990 to $74 \%$ in 2002 and there are presently more than 100 brands on the market (EMBRAPA, 2003).

So, with the government deregulation, changes have taken place in the dairy industry, in farms (i.e., production location and farm size) and consumers' profile (i.e., product quality), and in processing techniques (i.e., UHT milk). In this context, it is important to identify how the price liberalization affects the integration between different regions in Brazil.

What are the changes in the spatial integration of the market and in milk price formation at the farm level after deregulation? This problem is important to the development of the dairy sector and has not been studied in Brazil. It is known that changes in the interaction among markets promote a reorganization on each market, which can cause positive or negative impacts in the regional level, depending on the magnitude and adjustment dynamics of the changes.

According to Goletti \& Christina-Tsigas (1995) and Santana (1998), the identification of integrated markets and the knowledge of milk price transmission among markets may help the government on delineating policies, which do not allow duplicity of interventions; permit to monitor the price movements, contributing with the stabilization policies; and, lastly, contribute with the infrastructure of commercialization policies, helping on the stocks and tariffs definition, and trade flow dynamics. Ravallion (1986) revealed that this kind of study is important to detect key-regions on policies propagation. Therefore, this study is important for the delineating of regional development policies. 


\section{Methodology}

The utilized analytical model is based on Gonzalez-Rivera \& Helfand (2001), but with some modifications, which are DAG, Bernanke decomposition, and impulse response functions. It is divided in three parts: extension of the market, pattern of integration, and degree of integration. The extension of the market is determined through the measure of a self-sufficiency index, unit root test, and Johansen test. The last one is focused on the searching for a common trend between the time series, as recommended by Gonzalez-Rivera \& Helfand (2001). The pattern of integration is studied using the Directed Acyclic Graph (DAG). Lastly, the degree of integration is measured by the impulse response functions derived by the Bernanke decomposition.

\subsection{Extension of the market}

\subsubsection{Index of Self-sufficiency (ISS)}

The ISS is given by ratio of the state's production share to its consumption share. The proxy for state consumption is made by multiplication between population and per capita consumption in each state. The closer to 1 , the closer to self-sufficiency is a state. Values larger than 1 indicate that a state is a net milk exporter, while values smaller than 1 indicate that the state is a milk importer.

\subsubsection{Common integrating factor}

After identifying the states that are connected by trade, we begin the search for those states that share the common integrating factor, i.e., those states that have the same trend in the long run. The existence of one and only one integrating factor for all series is obtained when the prices are cointegrated, and there are $n-1$ cointegrating vectors (GONZALEZ-RIVERA \& HELFAND, 2001). For this, we used the Augmented Dickey-Fuller (ADF) test to check the stationarity of the series, which is given by

$$
P_{t}-P_{t-1}=\Delta P_{t}=\alpha+\beta t+\delta P_{t-1}+\sum_{k=1}^{p-1} \sigma \Delta P_{t-k}+\varepsilon_{t}
$$

where $P_{t}$ represents the milk price series in each state of Brazil; $\alpha$ refers to $\mathrm{drift} ; \beta$ refers to a deterministic trend coefficient; $t$ is time; $\delta$ refers to the existence of a unit root in the series $P_{t} ; k$ is the number of lags; and $\varepsilon_{t}$ is an errors vector. If we determine that the price series in every state of Brazil is nonstationary, we can proceed to the Johansen test. If the opposite is found, those milk prices that show stationarity are excluded, since the cointegration analysis requires that all the time series present the same order of integration (ENDERS, 2005). 
The initial point in the Johansen procedure is the vector autoregressive model (VAR)

$$
\Delta P_{t}=\alpha+\Gamma_{1} P_{t-1}+\Gamma_{2} P_{t-2}+\ldots+\Gamma_{n-1} P_{t-n+1}+\varepsilon_{t}
$$

where $\alpha$ is a vector of constants; $\Gamma_{i}$ is a matrix of coefficients relating series changes at lagged $i$ period to current changes in the series; and $\varepsilon_{t}$ is a vector of independent identically distributed (IID) errors (MADDALA \& KIM, 1998).

With the Johansen procedure, it is possible to determine the locations that belong to the same physical market. In this sense, we decided to start the search for a common factor using a bivariate model, because it is not possible to work with all states together (Brazil has 26 states). The maximum number seems to be 5 because the cointegration approach does not allow a high number of variables. It is a numerical methods problem. As the cointegration works with matrices, this problem comes from the condition number of the matrix. All matrices have a condition number defined by the maximum eigenvalue over the minimum eigenvalue. The condition number gives a bound on how inaccurate the solution of a regression will be after the approximate solution. The condition number measure the sensitivity of a matrix or a linear system to numerical problems (DEDIEU, 1996). Matrices with condition numbers near 1 are said to be well-conditioned, which is signal of a good accuracy of the results. Matrices with condition numbers greater than one (such as around $10^{5}$ for a $5 \times 5$ Hilbert matrix) are said to be ill-conditioned. It is practically a singular matrix and the solution is prone to large numerical errors (DEDIEU, 1996). For example an equation $A x=b$, if the condition number is large, even a small error in $b$ may cause a large error in $x$.

So, we tested the cointegration between pairs of states. With this result, we can exclude those states that are not cointegrated. Afterward, we can test the multivariate model, i.e., those states that present cointegration in pairs was grouped. Again, we tested the existence of a common trend on these groups, using the Johansen Procedure. Each group was tested for the presence of $k-1$ cointegrating vectors. If the group denotes $k-1$ cointegrating vectors, it means that the states in this group have a common trend.

\subsection{Pattern of integration}

\subsubsection{Directed Acyclic Graphs (DAG)}

The pattern of interdependence is analyzed through DAG. DAG is a relative new methodology in the economics environment. We chose to work with DAG models, because they can determine in which market innovations the price discovery happen, as well as the direction in which price shocks flow. On the other hand, the VEC model (chose by Gonzalez-Rivera and Helfand) does not 
provide clear information about the direction of causation and leadership among locations. In recent studies, DAG has been used to analyze contemporaneous causal relationship, identifying the restrictions for structural VAR models (AWOKUSE \& DUKE, 2006).

The main idea of the DAG is to represent the causal relationships among a set of variables and present them in an arrow graph or picture. In our case, the causation represents the possibility of changing the effect variable $Y$ by changing the cause variable $X$. It is based on identifying restrictions in the innovation correlation matrix $(\Sigma)$ from the VAR (BESSLER, 2006).

For definition, "a directed graph $G$ is a causal graph for $C$ if there is a directed edge or node from $X$ to $Y$ in $G$ if and only if $X$ is a direct cause of $Y$ relative to $C$ " (SPIRTES et al., 2006). Using a mathematical definition, "graph is an ordered triple $\langle V, M, E\rangle$, where $V$ is a non-empty set of vertices (variables); $M$ is a non-empty set of marks (symbols attached to the end of undirected edges); and $E$ is a set of ordered pairs" (BESSLER, 2006).

In this study, we used the TETRAD 4.3.7-3 to work with DAG. The TETRAD has three distinct parts: a picture or graph to represent the causal relations among the variables; a specification of the family of probability distributions and kinds of parameters associated with the graphical model; and a specification of the numerical values of those parameters (BESSLER, 2006).

In this study, a recursive structural equation model (RSEM) refers to a VAR model. So, the price in each state of Brazil included in the VAR is a node in the DAG, and the covariance matrix generated by the VAR is the input for the DAG.

The software uses the PC algorithm that begins with an undirected graph in which all the variables are originally connected. The program proceeds stepwise to remove adjacent edges when partial (conditional) correlations are not statistically significant from zero at an identified significance level and assigns causal flow directions for the remaining edges (BESSLER, 2006). The Fischer's $z$ is used to test the significance of the conditional correlation (BESSLER, 2006).

In this sense, we used the VAR results obtained in the software JMulti as an input to the DAG analysis with Tetrad. Therefore, the results of DAG worked as information to help the placing of zeros on the VAR innovations through Bernanke decomposition, and consequently, to create the impulse response functions at JMulti.

\subsection{Degree of integration}

The degree of integration is analyzed via the impulse response functions. However, in order to do the impulse response functions, we need to orthogonalize the innovation accountings from the VAR. There are many equivalent representations of the VAR model. Therefore, we chose the Bernanke decomposition, or structural VAR to treat the innovation accountings from the VAR. 


\subsubsection{Bernanke decomposition}

Bernanke decomposition is an orthogonalization based on the assumptions that distinct, mutually orthogonal, behavioral shocks drive the model, and that lagged relationships among the variables are not restricted (AWOKUSE \& DUKE, 2006). In contrast to Choleski decomposition (the most common decomposition), Bernanke decomposition relaxes the assumption of a just-identified structure of the innovation accounting. It allows the imposition of over-identifying restrictions on the model (RATS Manual, 2004). However, Bernanke (1986) states that for a VAR in $n$ variables, if we leave more than $n(n-1) / 2$ parameters free (to be estimated) the model is not identified.

Haigh et al. (2001) affirmed that Choleski factorization can bias the results because the correct structural model is not known. Bernanke decomposition is particularly interesting since it relies on prior theory as the source of their identifying restrictions. It means that the cointegration test and the correlation among the variables is used as information for the Bernanke decomposition.

Therefore, following Spirtes et al. (2000) we can identify the contemporaneous relationships among the variables based on the covariance matrix from residuals from the VAR by using DAG. DAG offers help in providing database evidence of ordering in contemporaneous time $t$, assuming the information set on variance-covariance matrix is causally sufficient (YU \& BESSLER, 2006). It means that DAG will give us the information to place zeros on the VAR innovations. However, Bernanke (1986) states that for a VAR in $n$ variables, if we leave more than $n(n-1) / 2$ parameters free (to be estimated) the model is not identified. It means that in a $(6 \times 6)$ matrix, we are able to identify 21 parameters, i.e., the 6 diagonal elements and 15 nonzero elements.

\subsubsection{Impulse response functions}

Impulse response functions provide the effect of a one-time shock in one of the system's series on itself and on other series in the system (HAMILTON, 1994). In other words, this concept allows analyzing the impact of shocks and the way in which shocks are transmitted among markets. In this study, we considered a one-time shock in one variable (price) to see the response in 24 months.

\subsection{Data}

The nominal price series was collected in the FGV (Fundação Getúlio Vargas). We made use of the monthly milk price for every Brazilian state between July 1994 and September 2005. However, Tocantins, Maranhão, Amazonas, Amapá, Alagoas, Piauí, and Roraima presented significant discontinuities in the time series, which makes them unacceptable for econometric modeling. It is not the best kind of data for this research. However, it is the only data available in Brazil.

We did not use the real prices because we believe that if we deflate the prices, we are already creating a tendency. Consider two time series $P_{1}$ and $P_{2}$. If we deflate the 
series, we have $P_{1,2}=P_{1,1}$. I and $P_{2,2}=P_{2,1} . I$, where $I$ is the deflator index. Combining them as occurs in a cointegration test, it is easy to find that $P_{1,2}-P_{2,2}=\left(P_{1,1}-P_{2,1}\right)$. I. Therefore, deflating a price series creates a trend between them. So, since the cointegration test tries to find a common tendency between multiple time series, it does not make sense to input a trend before running the cointegration test.

The time period was established based on the following information. Firstly, it includes the post-liberalization period of the milk market in Brazil (1991). Secondly, it is after the Plano Real. Plano Real was the most important economic plan in Brazil (1994).

Consumption, population, and production data was collected at IBGE (Instituto Brasileiro de Geografia e Estatística). Data referring to dairy consumption are available on Pesquisas de Orçamento Familiar (POF) for 1987, 1996, and 2002. However, for 1987 and 1996, there is only data for the main capitals of Brazil (São Paulo, Rio de Janeiro, Belo Horizonte, Belém, Curitiba, Fortaleza, Porto Alegre, Recife, and Salvador). Therefore, we decided to work solely with consumption data in 2002 , because it is the only data that approaches exactly what we need. Otherwise, we would have to make many assumptions that could cause bias in the results, since it will be the first step on the analysis.

We used the software JMULTI 4.14 (www. jmulti.de/download.html) and Tetrad 4.3.7-3 (www.phil.cmu.edu/projects/tetrad_download/launchers/). JMULTI was used to run the ADF test, cointegration, and VAR/VEC analysis, including Bernanke decomposition and the impulse response. The Tetrad run the DAG.

\section{Results}

\subsection{Extension of the market}

\subsubsection{Index of Self-sufficiency}

The ISS showed that only Paraíba is close to self-sufficiency in milk (0.977158). According to Gonzalez-Rivera \& Helfand methodology, it means that Paraíba does not need to trade (sell or buy) milk with other states. As a result, Paraíba is out of our analysis. Considering a level of $5 \%$ of significance, the ADF test showed that all the series are nonstationary, except Pará. It means that Pará was excluded from the rest of the analysis, because the cointegration test requires that all the series be nonstationary. Consequently, the cointegration in pairs was tested with 17 states.

\subsubsection{Common cointegrating factor}

\subsubsection{Cointegration in pairs}

As the number of cointegration tests between pairs of 17 states is quite large we are going to present a summary of the cointegration results in Table 1. 


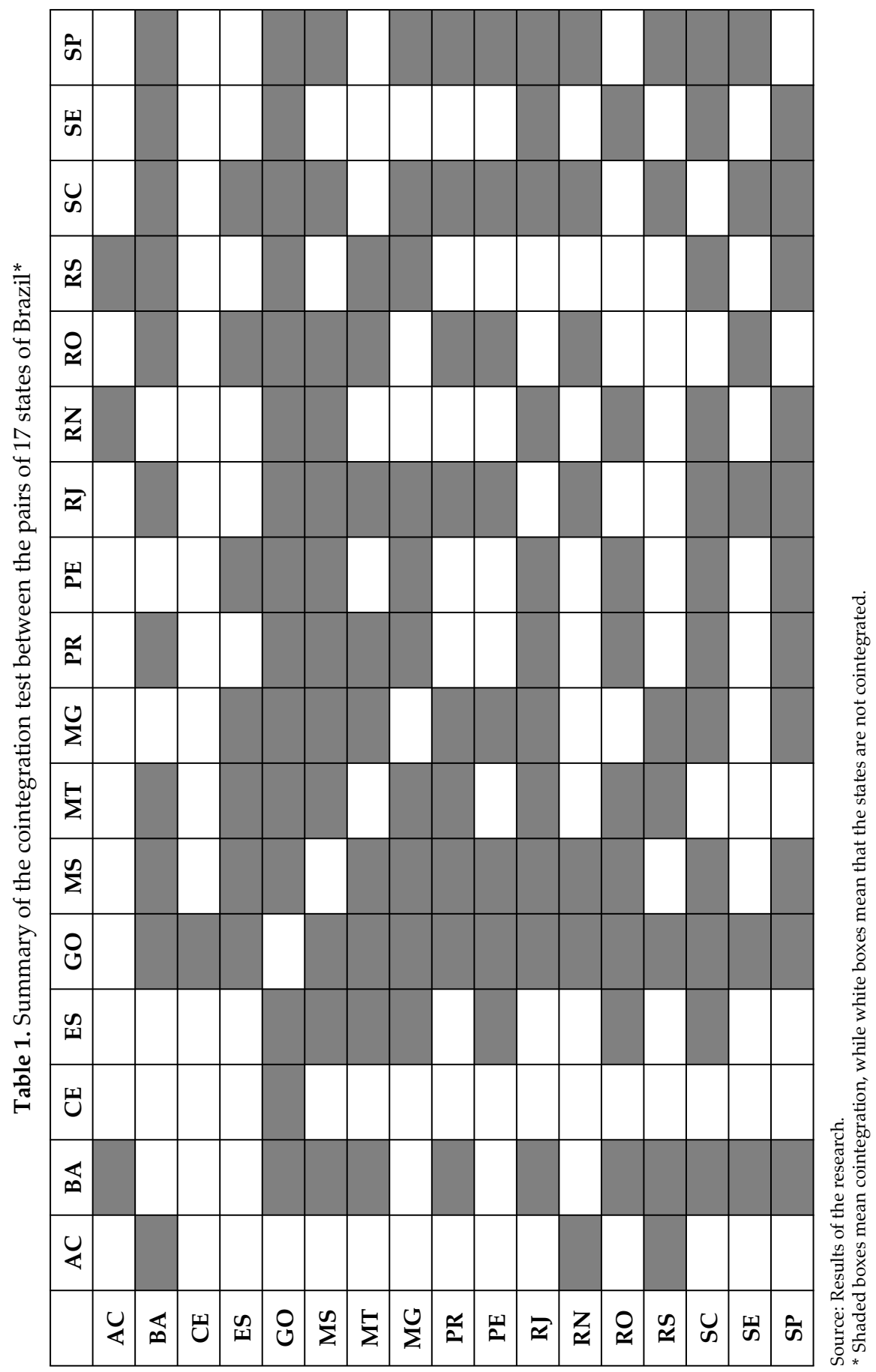

RESR, Piracicaba, SP, vol. 48, no 01, p. 41-61, jan/mar 2010 - Impressa em março 2010 
Table 1 shows a certain level of division between the Brazilian states. Except for Bahia, the first states on the list of the number of cointegrating relationships between the prices are all from the regions Center-West, South, and Southeast. However, it is an expected result, since the production, consumption, and processing of milk occurs in the Southeast, Center-West, and South of Brazil. On the other side, the last positions belong to states from North and Northeast, which are not traditional regions in dairy production or processing.

\subsubsection{Cointegration in groups}

After the pairwise test, we made groups of states in order to analyze the market integration. The main idea now is to make groups based on the results of the cointegration in pairs, i.e., those states that were cointegrated in pairs will be put together in order to make groups. Our previous tests indicated that those states that are cointegrated in pairs are more likely to be cointegrated in groups.

However, it is possible that some states that are not cointegrated with one of the others could be cointegrated with the group. Because of this, we reconsidered some non-cointegrated states when we make the groups. But if we did not find $(k-1)$ cointegrating relationships, we excluded or replaced the state that was not cointegrated with some of the others in the cointegration in pairs.

At this point, we followed the official Brazilian grouping (regions): North, Northeast, Center-West, South, and Southeast, which seems to make sense, since in Brazil the states in the same region have similar economical level of development. However, in the region North and Northeast, the states were not cointegrated in pairs. Therefore, we could test the cointegration among states within regions South, Southeast, and Center-West. We also tried different criterion to make groups of states, as for example, distance, ranking of production, consumption, etc. However, the space limitation does not allow us to present these results. We will be pleasured of presenting it if someone requests it. For now, we can only affirm that the results are very similar to the political groups. The first three groups were:

1. Paraná, Santa Catarina, and Rio Grande do Sul, representing the region South.

2. Minas Gerais, São Paulo, Rio de Janeiro, and Espírito Santo, as region Southeast.

3. Goiás, Mato Grosso, and Mato Grosso do Sul, as region Center-West.

We can also make groups associating regions as

4. Center-West and South: Goiás, Mato Grosso or Rio Grande do Sul, Mato Grosso do Sul, Santa Catarina, and Paraná.

5. South and Southeast: Santa Catarina, Paraná, Minas Gerais, São Paulo, and Rio de Janeiro or Rio Grande do Sul or Espírito Santo.

6. Center-West and Southeast: Goiás, Mato Grosso do Sul, Minas Gerais, São Paulo, and Rio de Janeiro or Mato Grosso. 
Table 2. Results of the cointegration test for group 1 to 5 .

\begin{tabular}{|c|c|c|c|c|c|}
\hline \multirow{2}{*}{ Group } & \multirow{2}{*}{ rank } & \multirow{2}{*}{ LR } & \multicolumn{3}{|c|}{ Critical values } \\
\hline & & & $10 \%$ & $5 \%$ & $1 \%$ \\
\hline \multirow{3}{*}{$\begin{array}{l}\text { 1. Region South: } \\
\text { Paraná - Santa Catarina - } \\
\text { Rio Grande do Sul }\end{array}$} & $r=0$ & 62.35 & 39.73 & 42.77 & 48.87 \\
\hline & $r \geq 1$ & 27.18 & 23.32 & 25.73 & 30.67 \\
\hline & $r \geq 2$ & 5.86 & 10.68 & 12.45 & 16.22 \\
\hline \multirow{3}{*}{$\begin{array}{c}\text { 2. Region Southeast: } \\
\text { Minas Gerais - São Paulo - } \\
\text { Rio de Janeiro }\end{array}$} & $r=0$ & 44.49 & 39.73 & 42.77 & 48.87 \\
\hline & $r \geq 1$ & 24.97 & 23.32 & 25.73 & 30.67 \\
\hline & $r \geq 2$ & 8.28 & 10.68 & 12.45 & 16.22 \\
\hline \multirow{3}{*}{$\begin{array}{l}\text { 3. Region Center-West: } \\
\text { Goiás - Mato Grosso do Sul - } \\
\text { Mato Grosso }\end{array}$} & $r=0$ & 68.89 & 39.73 & 42.77 & 48.87 \\
\hline & $r \geq 1$ & 24.96 & 23.32 & 25.73 & 30.67 \\
\hline & $r \geq 2$ & 6.82 & 10.68 & 12.45 & 16.22 \\
\hline \multirow{5}{*}{$\begin{array}{l}\text { 4. Center-West and South: } \\
\text { Goiás - Mato Grosso do Sul - } \\
\text { Paraná - Santa Catarina - } \\
\text { Rio Grande do Sul }\end{array}$} & $r=0$ & 172.52 & 84.27 & 88.55 & 96.97 \\
\hline & $r \geq 1$ & 84.61 & 60.00 & 63.66 & 70.91 \\
\hline & $r \geq 2$ & 51.19 & 39.73 & 42.77 & 48.87 \\
\hline & $r \geq 3$ & 24.72 & 23.32 & 25.73 & 30.67 \\
\hline & $r \geq 4$ & 6.53 & 10.68 & 12.45 & 16.22 \\
\hline \multirow{5}{*}{$\begin{array}{l}\text { 5. South and Southeast: } \\
\text { Santa Catarina - Paraná - } \\
\text { Minas Gerais - São Paulo - } \\
\text { Rio de Janeiro }\end{array}$} & $r=0$ & 183.98 & 84.27 & 88.55 & 96.97 \\
\hline & $r \geq 1$ & 110.63 & 60.00 & 63.66 & 70.91 \\
\hline & $r \geq 2$ & 62.99 & 39.73 & 42.77 & 48.87 \\
\hline & $r \geq 3$ & 25.86 & 23.32 & 25.73 & 30.67 \\
\hline & $r \geq 4$ & 5.99 & 10.68 & 12.45 & 16.22 \\
\hline \multirow{5}{*}{$\begin{array}{l}\text { 6. Center-West and Southeast: } \\
\text { Goiás - Mato Grosso do Sul - } \\
\text { Minas Gerais - São Paulo - } \\
\text { Rio de Janeiro }\end{array}$} & $r=0$ & 169.41 & 84.27 & 88.55 & 96.97 \\
\hline & $r \geq 1$ & 81.54 & 60.00 & 63.66 & 70.91 \\
\hline & $r \geq 2$ & 50.93 & 39.73 & 42.77 & 48.87 \\
\hline & $r \geq 3$ & 26.72 & 23.32 & 25.73 & 30.67 \\
\hline & $r \geq 4$ & 4.59 & 10.68 & 12.45 & 16.22 \\
\hline
\end{tabular}

Source: Results of the research.

Table 2 shows us that all the states in South and Center-West are cointegrated. However, in the Southeast region, only Minas Gerais, São Paulo, and Rio de Janeiro were cointegrated.

We also found out that the states in Center-West and Southeast were cointegrated with each other when we included Rio Grande do Sul, instead of Mato Grosso. The same thing happened between Center-West and Southeast. They were cointegrated if we include Mato Grosso, but not cointegrated if we use Rio de Janeiro. Similarly, between South and Southeast, there was cointegration if we replace Rio Grande do Sul for Rio de Janeiro.

By this analysis, we conclude that most of the states in South, Southeast, and Center-West of Brazil were cointegrated. It means that their prices move together 
in the long-run, and they represent a single market. There is a flow of milk and information among these states. Nevertheless, there are some problematic states in this analysis. They are Espírito Santo, Rio de Janeiro, Rio Grande do Sul, and Mato Grosso. Sometimes, these states showed cointegrating relationships with the states in other regions, and other times they are the cause of the non-cointegration.

These results give us important information about the extension of the market in Brazil. It indicated that the milk market in Brazil concentrates in the Center-West, Southeast, and South (Figure 1). The different groups demonstrated that geographical location is a determining characteristic for the Brazilian milk market. We found out that the states geographically close have a common trend between the milk prices and represent the Brazilian milk market. In other words, the extension of the Brazilian milk market is likely given by Mato Grosso, Goiás, Mato Grosso do Sul, Minas Gerais, Rio de Janeiro, São Paulo, Paraná, Santa Catarina, and Rio Grande do Sul. The limitations of the methodology do not allow us to assure it. However, the results of the test strongly indicate it. Especial attention should be given to Rio de Janeiro, Mato Grosso, and Rio Grande do Sul, because they demonstrated to be cointegrated in certain cases, but not in others. It is also an interesting result, since these three states represent the extreme boundaries of the Brazilian milk market. This reaffirms that the geographically proximity is a very important feature of a market. Mato Grosso is the northwest extreme; Rio de Janeiro is the east; and Rio Grande do Sul is the south extreme. It likely happens because of the transportation cost.

Figure 1. Brazilian milk market

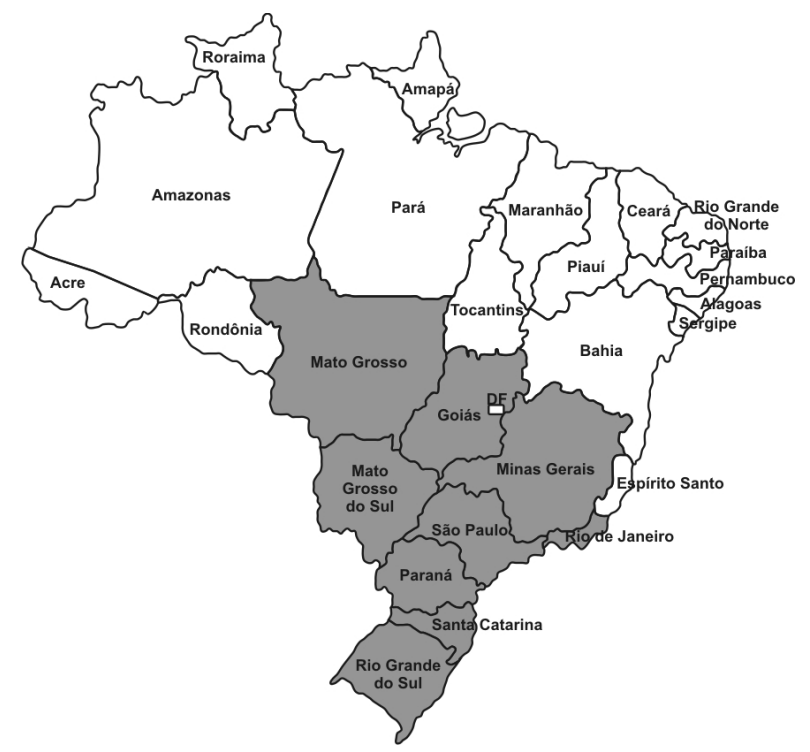

Source: Results of the research. 


\subsection{Pattern of integration}

\subsubsection{Directed acyclic graphs}

The pattern of interdependence was analyzed by DAG. In the DAG analysis, we used the PC algorithm, and a p-value of 0.01 , as recommended by Awokuse \& Duke (2006), for a sample size between 100 and 300. We analyzed the pattern of interdependence using the same groups of states established previously.

Figure 2. Directed Acyclic Graphs (DAG) for the 6 groups studied

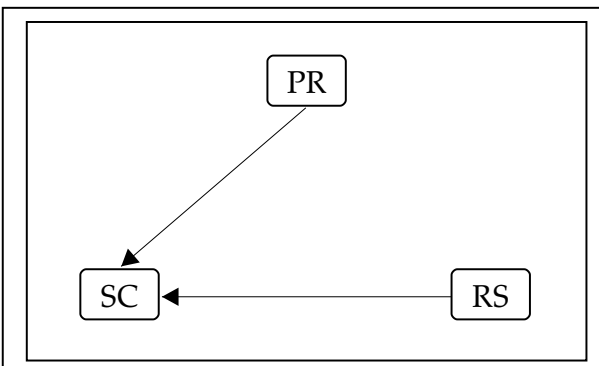

1. South

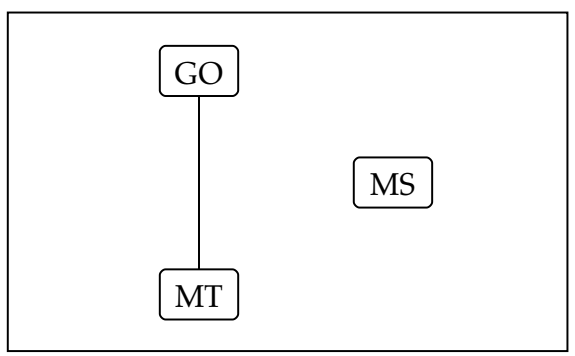

3. Center-West

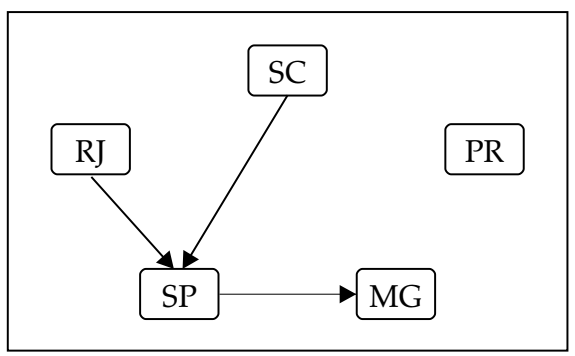

5. South + Southeast

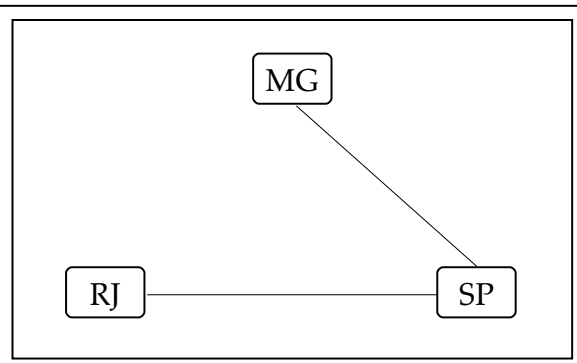

2. Southeast

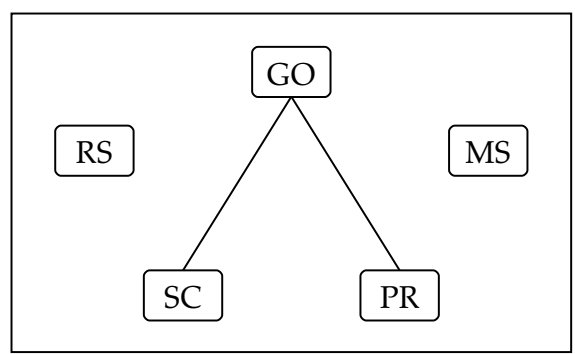

4. South + Center-West

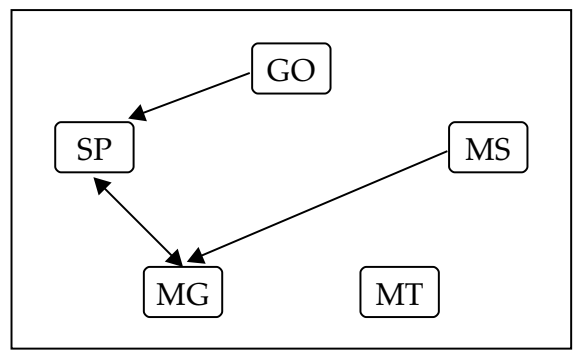

6. Southeast + Center-West

Source: Results of the research. 
The first graph shows the results of the DAG analysis for the region South (Figure 2). It demonstrates that the milk price in Rio Grande do Sul (RS) and Paraná (PR) cause the milk price in Santa Catarina (SC). However, the DAG's results state that the milk prices in Rio Grande do Sul, as well as Paraná, are caused by the price in another state out of the region South or by other market elements (i.e., exports, processors, etc). The results of the DAG for Rio Grande do Sul seem reasonable, because this state is the leading milk production state in the region South of Brazil during all the period analyzed. The p-value for this model is 0.49589855. According to Awokuse \& Duke (2006), in the DAG analysis, $\mathrm{p}$-values higher than 0.01 are reasonable, while higher than 0.05 are great

It is important to note the leader supported by DAG is the leading production state in the South, which it is quite reasonable since we are studying farm level prices. However, the results for the other regions evidenced that the there is not a national leader at the Brazilian milk market. For example, the second graph shows that there are certain interdependencies between Minas Gerais (MG), São Paulo (SP), and Rio de Janeiro (RJ) (Figure 2). However, there is not a cause-effect relationship in this region. It means that the prices in these three states are connected and correlated, but they are not caused by any other state in the Southeast of Brazil. There is not a leader in milk price formation in the region Southeast, which is quite understandable because all the states in this region are economically developed, and have a great level of production and consumption of milk.

The third graph shows that the milk price in Goiás (GO) and Mato Grosso(MT) are interdependent, but they do not cause each other (Figure 2). However, Mato Grosso do Sul is presented as independent of the others. It might be that Mato Grosso do Sul has been influenced by the states out of the region Center-West. Mato Grosso do Sul is located in a strategic position. It is connected with the two states in the Center-West (Mato Grosso and Goiás), two states in the Southeast (Minas Gerais and São Paulo), and one state in the South (Paraná). Therefore, it is likely that Mato Grosso do Sul are receiving influence of these three regions.

The fourth graph shows that there is some level of independence among the states in Center-West and South of Brazil. Goiás (GO), Santa Catarina (SC), and Paraná (PR) are interconnected, but the cause-effect relationship between them is not well defined (Figure 2). On the other hand, Mato Grosso do Sul (MS) and Rio Grande do Sul (RS) are completely independent of the other states in these analysis. It is intriguing, since Rio Grande do Sul was showed as the cause of the price in Santa Catarina (Graph 1). Instead of its location, Mato Grosso do Sul is still not correlated with the others (Graph 3).

The fifth graph indicates that there is interdependence among the states in South and Southeast of Brazil (Figure 2). It points out that Santa Catarina (SC) and Rio de Janeiro (RJ) causes São Paulo's milk price, while São Paulo (SP) causes Minas Gerais' prices, and Paraná (PR) is independent of the other states. Rio de Janeiro causing São Paulo does not make sense, because the second one is more important in milk 
production, processing, and consumption than the first one. However, the DAG analysis should not be taken in consideration, since the p-value associated with it is 0.00003625 , which is too small. In the DAG analysis, $\mathrm{p}$-values higher than $1 \%$ are good.

The sixth graph shows a leadership of Mato Grosso do Sul (MS) and Goiás (GO); with Goiás causing São Paulo (SP); São Paulo and Minas Gerais (MG) causing each other; Mato Grosso do Sul causing Minas Gerais and Mato Grosso (MT) is not caused or cause any other state (Figure 2). However, it is interesting that there is no relationship among the states of Center-West when they are associated with other regions.

Moreover, we can notice from the analysis that the definition of the causal relationship between the milk prices in Brazil is not an easy work. The DAG analysis presented ambiguous results. It signifies that the relationships between the states in the milk market still undetermined. 15 years after the deregulation, this market is still developing and trying to adapt to the new reality. Another reason for this would be that the data used is by state, while the recommended data would be by processor or by production zone. Since the multinational processors exert market power, affecting the milk price, it may influence the performance of the DAG analysis.

\subsection{Degree of integration}

\subsubsection{Bernanke decomposition and Impulse response functions}

Since the region South was the only one that presented undirected acyclic graphs, it is possible to apply the Bernanke decomposition and run the impulse response functions for the South of Brazil.

Figure 3. Set of impulse response functions for the region South.

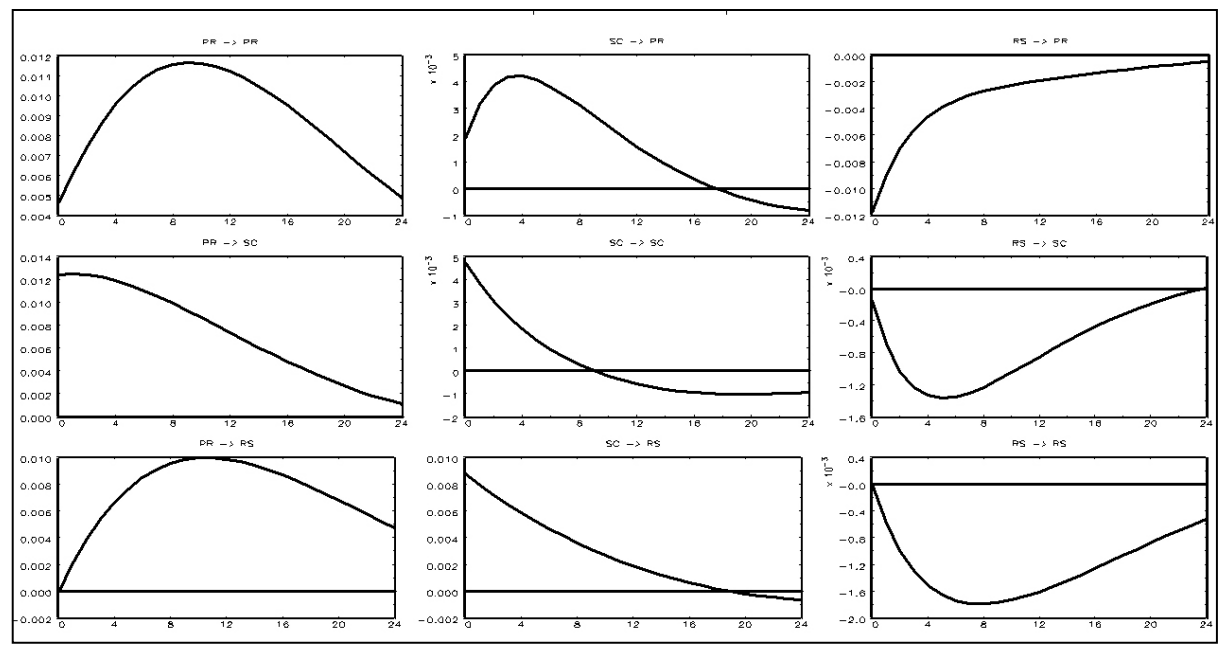

Source: Results of the research. 
Figure 3 shows small adjustment to shocks in the region South. It may be a reflection of the instability of the economy in Brazil. The milk prices, as well as other commodity prices, suffer the consequences of the instability of the economy, and hence, they had difficulty to adjust to shocks.

Another fact that may influence this result is that the milk production is a seasonal or annual activity. It means that the producers plan the production 6-12 months before, and once planned (i.e., once buy the input and equipments) it is hard to change the production quickly. The farmers are not able to change their planning quickly, and hence it takes at least one year or two to the activity adjust to disequilibria.

Moreover, it evidences price inefficiency in the Brazilian milk market, which may be reflex of the oligopsony situation. It indicates that processors in each state adjust price slowly. The information is not flowing correctly in this market. One alternative for this would be the futures markets for milk. According to the literature, one of the functions of the futures markets is to allow a better flow of information among markets and, hence, come the system price more efficient.

\section{Conclusion}

In this paper, we chose a modification of the Gonzalez-Rivera \& Helfand (2001) methodology, which is divided into extension of the market, pattern of integration, and degree of integration.

One modification that we made in Gonzalez-Rivera \& Helfand (2001) methodology was to use nominal prices instead of real prices. Due to the fact that we were interested in analyzing the milk price formation in Brazil, we thought that the nominal price would be more approppriate.

The results suggest that the extension of the milk market in Brazil is composed of states from South, Southeast (except Espírito Santo), and Center-West: Rio Grande do Sul, Santa Catarina, Paraná, Minas Gerais, Rio de Janeiro, São Paulo, Mato Grosso, Mato Grosso do Sul, and Goiás. All states seem to follow the same milk price movement in the long-run. On the other hand, states from North and Northeast of Brazil have local milk markets. We also conclude that the geographic proximity (as well as the transportation costs) are determining of the extension of the market. It is a useful information, since the policymakers know that some states are not integrated because of the transportation costs. So, they can act on the transportation costs to improve the integration among the states in Brazil.

As an implication, we can say that this analysis will be very useful especially for policymakers on the milk market in Brazil. They will need different policies for different markets, i.e., one policy for the national market (South, Southeast, and Center-West) and another one for the local markets (North, Northeast, and Espírito Santo). 
Regarding the pattern of integration among the states, we did an analysis within each group, because of the limitations of the methodology. We found that there is a mix of causation, depending on which group of states we considered. It may indicate that the milk market in Brazil is still developing, and the period analyzed was not able to catch all the rearrangements on this market. We conclude that the states in the Brazilian milk market are integrated with each other, but there is not a leader in this market. It means that several states are important in milk price formation in Brazil. Because of this, the policies need to be applied in all states, instead of one leader state.

The results the impulse response analysis, indicated that the states in the South of Brazil are integrated with each other, but a shock in one state causes a slow response in the others. It implies that there are inefficient prices in the Brazilian milk market, which may be reflex of the oligopsony situation. It indicates that processors in each state adjust price slowly. The information is not flowing correctly in this market. One alternative for this would be the futures markets for milk. On the other hand, the slow adjustment might be positive for the milk market, since in an instable economy as in Brazil, the crisis in one state will be transferred slowly for the other states.

In sum, the government can use this information to improve the integration of the milk market, including the North and Northeast in the national market, to work on the stabilization of this market; to develop the milk trade and flow within the country; to predict the price movement after economic shocks, etc. We also believe that this research provides useful information to build the milk price index to the milk futures contracts in Brazil.

\section{Reference}

AWOKUSE, T.O.; DUKE, J.M. “The causal structure of Land Price Determinants." Canadian Journal of Agricultural Economics. v. 54, pp. 227-245, 2006.

BARRETT, C.B. "Measuring integration and efficiency in international agricultural markets." Review of Agricultural Economics, v. 23, pp. 19-32, 2001.

BERNANKE, B. S. Alternative explanations of the money-income correlation. Carnegie-Rochester Conference Series on Public Policy. v. 25, pp. 49-99, 1986.

BESSLER, D.A. "Unpublished Lecture Notes: Frontiers in Markets and Information," Department of Agricultural Economics, Texas A\&M University, Fall, 2006.

DEDIEU, T. Approximate solutions of numerical problems, condition number analysis and condition number theorem. In: Lectures in Appl. Math., vol.32. Amer. Math. Soc., Providence, RI. pp. 263-283. 
EMPRESA BRASILEIRA DE PESQUISA AGROPECUÁRIA - Gado de Leite (Embrapa). Banco de dados econômicos. 2008. Available at: <www.cnpgl.embrapa.br > . .2003. Available at: <www.cnpgl.embrapa.br >

ENDERS, W. Applied Econometric Time Series. New York: John Wiley, 2005.

FACKLER, P.L.; GOODWIN, B.K. Spatial price analysis. Handbook of Agricultural Economics. 2000, pp. 1-59.

GOLETTI, F.; CHRISTINA-TSIGAS, E. Analyzing market integration. In: Scott, G.J., ed. Prices, products, and people: analyzing agricultural markets in developing countries. Boulder: Lynne Riener, 1995.

GOMES, A.L. "O comportamento do preço do leite recebido pelo produtor: uma abordagem de curto e longo prazo." MS thesis, Universidade Federal de Viçosa, 2003.

GOMES, A.T.; LEITE, J.L.B.; CARNEIRO, A.V.; GOMES, A.L. "Formas e mecanismos de relacionamento entre indústrias e produtores de leite: casos de sucesso." Congresso Brasileiro de Economia e Sociologia Rural, Passo Fundo, RS, 2002.

GOMES, S.T. "Cadeia agroindustrial do leite no Mercosul." In: W.C. Vieira; F.M.A. Carvalho (eds.). Mercosul: agronegócios e desenvolvimento econômico. Imprensa Universitária: Universidade Federal de Viçosa, 1997, pp. 155-176.

GONZÁLEZ-RIVERA, G.; HELFAND, S.M. The extent, the pattern and degree of market integration: a multivariate approach for the Brazilian Rice Market. American Journal of Agricultural Economics v. 83, n. 3, pp. 576-592, 2001.

GONZALO, J.; GRANGER, C.W.J. "Estimation of Common Long-Memory Components in Cointegrated Systems. J. Buss. Econ. Stat. v. 13, pp. 27-35, January 1995.

HAIGH, M.S.; NOMIKOS, N.K.; BESSLER, D.A. Integration and Causality in International Freight Markets - Modeling with Error Correction and Directed Acyclic Graphs. Working Paper 02-11. Department of Agricultural and Resource Economics.University of Maryland, College Park, 2001.

HALL, S.G.; MILNE, A. The Relevance of P-Star Analysis to UK Monetary Policy. The Economic Journal v. 104, n. 424, pp. 597-604, 1994.

HAMILTON, J. Time Series Analysis, Princeton University Press, Princeton New Jersey, 1994.

IBGE. 2006. Available at: <www.ibge.gov.br>. 
LIU, Q.; WANG, H.H. "Market Integration Test for Pacific Egg Markets." American Agricultural Economics Association Annual Meeting, Montreal, Canada, pp. 27-30, July 2003.

MADDALA, G.S.; KIM, I. Units roots, cointegration, and structural change. Cambridge: Cambridge University Press, 505 p. 1998.

MARTINS, P.C. "O sistema agroindustrial do leite: transações e incentivos à adoção de tecnologias." Congresso Internacional de Economia e Gestão de Negócios Agroalimentares, Ribeirão Preto, SP, 1999.

MASCONI, R.; GIANNINI, C. "Non-causality in Cointegrated Systems: representation, estimation and testing." Oxford Bulletin of Economics and Statistics, v. 54, n. 3, pp. 399-418, 1992.

MILKPOINT. Giro Lácteo. 2005. Available at: <www.milkpoint.com.br>.

MOSER, C.; BARRETT, C.B.; MINTEN, B. Missed opportunities and missing markets: Spatio-temporal arbitrage of rice in Madagascar. American Agricultural Economics Association Annual Meeting, Providence, Rhode Island, pp. 24-27, July 2005.

PEREIRA, L.R. PhD Thesis. Universidade Federal de Viçosa, 2005.

RASHID, S. Spatial integration of maize markets in post-liberalized Uganda. Markets, trade and Institutions Division, International Food Policy Research Institute, 2004. Available at: <www.agecon.lib.umn.edu>.

RATS Manual, Estima, 2004.

RAVALLION, M. Testing market integration. American Journal of Agricultural Economics. n. 68, p. 102-109, 1986.

SANTANA, A.C. Comercialização e integração de mercado na pecuária de corte do Estado do Pará. In: Congresso Brasileiro de Economia e Sociologia Rural, 36. Poços de Caldas. Anais...Poços de Caldas, MG, 1998.

SPIRTES, P.; SCHEINES, R.; MEEK, C.; RICHARDSON, T.; GLYMOUR, C.; HOIJTINK, H.; BOOMSMA, A. TETRAD 3: Tools for Causal Modeling. User's Manual, 2006. Available at: < http://www.phil.cmu.edu/projects/tetrad/tet3/master.htm>.

TANNÚS, S.P. “Competitividade e importações: a produção leiteira em Minas Gerais." MS thesis, Universidade Federal de Viçosa, 2001.

YU, T.; BESSLER, D.A. Cointegration and Causality Analysis of World Vegetable Oil and Crude Oil Prices. American Agricultural Economics Association Annual Meetings, Long Beach, California, pp. 23-26, July 2006. 